\title{
Foundations of Ethics and Education in the Philosophy of Transcendentalism*
}

\author{
Sergei Nizhnikov \\ Department of the History of Philosophy \\ Peoples' Friendship University of Russia \\ 6, Miklukho-Maklaya Str. \\ Moscow, Russia \\ E-mail: nizhnikovs@mail.ru
}

\begin{abstract}
The author of the article reviews the main aspects of Immanuel Kant's philosophy of morality, education, and upbringing, which formed the European model of education in the $19^{\text {th }}-20^{\text {th }}$ centuries. The paper traces Kant's path to the moral interpretation of the spirituality as a truly universal interpretation, as opposed to the formerly used spiritualist one. The author treats transcendental philosophy as a possible basis for the development of the future model of education, in which it aims to rise above the particularism of metaphysical systems and traditional worldviews. This, according to the author, is its universal humanitarian crosscultural potential that can be used in the education of the subjects of the contemporary world, aimed at finding common spiritual and moral grounds.
\end{abstract}

Keywords-philosophy of education; Dasein; transcendental philosophy; ethics theology

\section{INTRODUCTION}

The modern philosophy of education faces the urgent need to form a positive ideology of the content aspect of education. What's especially important is the need for ideological enlightenment, the formation of stability in spite of all kinds of superstitions in a becoming and developing individual. Philosophy, in this case, is fundamentally important and irreplaceable. The said function of philosophy is well-manifested in the works of Immanuel Kant. Kant called the culture of virtue moral ascetics and dietetics, the purpose of which is to support oneself in a morally healthy state [1].

The systematic emergence of transcendental philosophy in Europe is associated with I. Kant, who was the first one to inspect existence in the perspective of consciousness rather than matter, as it was common for the preceding metaphysics [2]. In Eastern philosophy, the corresponding methodology was common to Buddhism. Nevertheless, Kant's discoveries are so significant, that M. Heidegger, e.g., called him "the first and the last scientific philosopher, the philosopher of the greatest after Plato and Aristotle scope"; "Kant's example calls us to sobriety and real work" [3].

* The publication has been prepared with the support of the "RUDN University Program 5-100".

\section{TRANSCENDENTAL PHILOSOPHY IN THE HISTORY OF PHILOSOPHY}

Kant identified the three stages in the development of philosophy: the first one he called the dogmatic stage, the second one - skeptical, the third one - critical, meaning the Critique of Pure Reason. At the first stage, philosophy took care only to prevent self-inconsistency in judgments (Plato, Aristotle, Leibniz, Wolff, etc.). The skeptical stage, according to Kant, comes later; there he refers, primarily, to D. Hume. And yet only the third stage decides the fate of metaphysics, defining the scope, content, and the limits of the a priori knowledge. If at the level of the first understanding, metaphysics appears in the form of a "infinite sea, in which the forward movement leaves no trace, and on the horizon there is no visible goal, by which one can judge how close we are to it", then only at the ultimate, critical, level metaphysics acquires a "stable state" [4].

Along with the emergence of transcendentalism, the idea of the subject and method of philosophy radically changes it "branches out" not only to the natural science but also to the symbol-creating activity of consciousness and its products. At the time of the philosophy's birth, this happened to mythology, then to science, and, finally, to the traditional understanding of metaphysics. Subjecting itself to selfreflection, philosophy cleanses itself and undergoes selfabsorption, following the infinite path to truth. According to Wilhelm Windelband, "the only remaining object is assessment"; from the means of cognition of the world philosophy turns into "science about normative consciousness" [5]. Heinrich Rickert explains further that because of the aforementioned process, philosophy didn't become redundant but the task, to which it had dedicated itself, among other objectives, is now only available in the pure state. "Philosophy leaves all the existence to the special sciences in order to question everywhere the meaning" [6]

Based on the principles of transcendental apriorism, the original point of philosophizing, i.e. the meditation on Self of an individual, is being completely rethought. Kant also imposes a ban on theoretical cognition of Self, on the metaphysics of spirit, as the preceding metaphysics couldn't think unbiased. Self can no longer be a thing among other 
things; it is not the matter in this sense: "The pathos of "unobjectness" of the human existence is organically linked in the Kant's world with the assertion of moral law" [7]. The spiritualistic interpretation is no longer possible, as it transforms into the spiritual morality.

The human essence exists, but it is nothing, its wealth is set by culture. Culture, deploying that nothing, fills it with content, providing interpretation. The method of cognition of nothing was already developed in the Upanishads ("not this, not this") [8]. Kant calls his philosophy transcendental and opposes it to the "transcendent" aspiration of the former metaphysics to cognize thing-in-itself. This opposition means that Kant declares the task of his philosophy to define the conditions of a priori cognition in all fields of human thinking. In this sense, transcendental is "everything that relates to the possibility of the universal essential content of our thought". According to Ernst Cassirer, "... the real, deepest task of the philosophy of culture, i.e. the philosophy of language, cognition, mythology etc., consists in breaking this veil - to return from the mediating sphere of meanings and signs back to the initial sphere of intuitive contemplation" [9].

In traditional metaphysics, ethics is based on axiomatic, transcendent foundations, in which the ontological and axiological aspects (the absolution is necessarily virtue) are merged. Such philosophy is seen as a "regulatory theology". That is, it is focused not as much as on achieving knowledge and truth, as on virtue; it is the latter that makes the final verdict about the "efficiency" and "inefficiency" of a philosophical system. Transcendental philosophy, firstly, seeks the truth, which can beget "actual" truth. The ideal of philosophical education is preserved here, but it is cleared of theology and teleology, their transcendent goals that sometimes "depreciate" individuals with the weight and significance of unconditional demands. The criterion of virtue rests on the a priori foundations of practical reason. Theology is accepted, but it leaves behind metaphysical form, taking instead the hypothetical form, turning thus into ethicstheology [10].

According to Kant, "Two human inventions may be considered the most difficult, namely: the art of control and the art of upbringing..."; "Parents take care of their family, the rulers - of the state. Both set as their ultimate goal the common good, and the perfection, to which humanity is destined..." [11]. The most seemingly simple and universal method of control is violence. Yet it lowers the human world to the level of animalism and barbarism. Only morality makes us human, homo sapience. Kant paid special attention to the topics of morality and upbringing after creating his magnum opus Critique of Pure Reason, in which he had laid the transcendental grounds of the philosophy of morality, education, and upbringing. Let us now reveal these philosophical premises.

\section{PRINCIPLES OF KANT'S ETHICSTHEOLOGY}

Kant builds, so to speak (using the phrase, coined by him himself), moral or transcendental theology (ethicstheology) on the basis of transcendental principles, since the speculative (metaphysical, transcendent) one was overthrown in the first Critique [12]. Moral theology, according to Kant, has the only immanent application. That is, it is intended to be brought to life in this world, without the direct connection of behavior with the idea of the Supreme Being (which would give the reason a transcendent implication). The ethicstheology should be based upon the objective belief of reason, and not on the subjective belief of an individual, that Kant sees as random. All this led Kant to the well-known and complete reassessment of the relationship of morality and religion: "...morality does not need religion at all; because of its pure practical reason, it is self-fulfilling". Nevertheless, "morality inevitably leads to religion" [14].

Kant relies on the moral disposition of an individual that is super-sensual but not supernatural. The philosopher denies any influence of mystical experiences in the sphere of faith, calling them "heartbreaking" and "heart-piercing". He criticizes the unnatural state of faith in the mystical sense when the subjective conditions of its emergence replace the goal, i.e. a virtuous life. Kant strived to pass between "orthodoxy and mysticism that mortifies reason". Morality as the basis of faith (religion), according to Kant, ends "where the human race ends", it is "initially the same for all people" because of having an a priori status. Critique of Pure Reason "has determined a person an exceptionally active existence in the world", as "a man himself is originally the creator of all his ideas and concepts and should be the only source of all his actions". The moral law "completely draws us out of [the shackles of] nature and raises us above it". This law provides "the quality of morality, inherent only to a human, distinguishing him from the rest of nature, making people independent and free beings...". And further: "It is the morality, not the reason that makes us human beings" [15] [16].

Transcendental philosophy, remaining essentially outside of disputes of metaphysical systems and traditional types of Weltanschauungen, is able to turn into a universal language of cross-cultural interaction and mutual understanding that is necessary in the contemporary globalizing world. The Russian post-Revolution philosophers S.N. Bulgakov, I.A. Ilyin, and S.L. Frank sought to achieve such a transformation of philosophy. As for the content of morality and the affirmation of freedom as its basis - this reveals the unity of critical (Kantian) and metaphysical (Russian) philosophy.

The conceptual difference between Kant's and the Russian religious thinkers' understanding of the essence of faith is as follows: if Kant strived to create, as noted, moral faith (or maybe even moral reason), then, in Russia, the philosophers discussed the metaphysics of faith. In this regard, it is possible to distinguish the following types of philosophical Weltanschauungen: transcendent, pantheistic (immanent), materialistic (naturalistic), transcendental (categorical-ontological (Kant)), and existential, fundamentally ontological (Heidegger). Each of them has its own peculiarities, in its own way seeks to solve the problems of human existence, justification of freedom and morality. Yet, the last one is fundamentally different from the first three, dealing with, to a degree objectified existence, whether 
it is super-existent, naturalistic or pantheistic. Transcendental Weltanschauung crucially tears down the connection of a person with a given objectified existence, defining it as a thing-in-itself (Kant), thus paving the way for its existential reading, removal of the dichotomies of the subject/object and transcendent/transcendental but at the same time preserving transcendence.

\section{HEIDEGGER'S INTERPRETATION OF TRANSCENDENTALISM}

Instead of transcendental deduction of categories, Martin Heidegger proceeds to the existential analysis of Dasein, which requires further in-depth study. A new metaphysics of non-transcendent type is opened, implicitly contained in the tradition of, first of all, early Greek type of philosophizing. Heidegger doesn't start from the Kant's critical pathos but seeks to reveal the opportunities within the Critique of Pure Reason in order to construct a new type of metaphysics as a fundamental ontology of Dasein. Heidegger believes that exactly the justification for such metaphysics was a "critique of pure reason" for Kant [17]. The true anthropology, according to Heidegger, is transcendental. Any other anthropology (transcendent, empirical-materialistic, etc.) knows already what an individual is, carries out the processing of ready-made symbols about the essence of humanity. Humanism, based on the symbols-creating activity of culture and consciousness, thinks the essence of a human to be alienated, therefore, possibly acquiring immoral forms. The culture of transcendental humanism requires a person to be self-sufficient in existence and doesn't provide any guarantees other than to satisfy a sense of morality. In it, as in philosophical Buddhism, there is no subject for faith and hope, although it cannot be denied. Even if there is a benevolent God, He cannot be described through consciousness, and everything is a myth. Yet, the heart knows about Him. But what the heart knows is located beyond kataphatic theology; traditional metaphysics only makes up the stories about it. Maybe the transcendental fundamental ontological method may reveal the mystery of a human about himself? This requires a transcendental analysis of existence. Heidegger's methodology "allows to productively treat a number of philosophical concepts (both in the past and present) as different modifications of "being" [18]. We may say that the German philosopher developed and applied a new historical-philosophical concept. In the post-Hegelian philosophy, this is the first attempt of such a deep and large-scale rethinking of the historicalphilosophical development [19].

Thus, it is possible to distinguish two types of philosophizing in the history of philosophy: transcendent (metaphysical) and transcendental, which emergence relates to I. Kant. Within their framework, there is a conceptually new interpretation of human Self, culture, the foundations of philosophy and morality. Based on the analysis of Kant's ethicstheology and Heidegger's fundamental ontology, we reveal the urge of transcendental philosophy for a new justification of spirituality and humanism in the globalizing world when the symbolic systems of the traditional cultures are unable to perform a unifying and morally-universal function. When humanity entered adulthood, it is possible to meditate on the independent from the traditional cultures grounds for Self and morality. Kant became the expression of a new culture springing up.

At the same time, the transition from one type of culture to another can be accompanied by a deep lapse into the lack of culture in its own sense, barbarism and lack of spirituality, into mass culture. It turned out that secular education is not always able to carry out the spiritual and cultural socialization which has been carried out for millennia by religion and metaphysics. Not only education is here to blame but also insufficient attention to it by society.

\section{CONCLUSION}

In the contemporary globalizing world, there is a demand for the experience of transcendental philosophy and fundamental ontology, as it seeks to identify a priory and, at the same time, universal values in a human and humanity. Global issues may only be resolved when humanity becomes a whole, leaving the state of the "youth" and going beyond the ethnic outlook towards a single culture and spirituality (created, based on the blossoming national cultures but not their rejection or decomposition), which only makes a person a true citizen of the world. This transcendental principle is inherent to all cultures but is interpreted as symbols of certain traditions, which can distort the essence, leading in the globalizing world to intercultural, worldview-related, interreligious, and civilizational contradictions, threatening the world with constant cataclysms.

In terms of society, education substitutes tradition and religion in terms of the moral and spiritual upbringing of a person, a task, in a traditional society usually performed by religion. Only in this case, transcendental philosophy will be able to find its own basis in a society and to acquire the transformative power that will help to overcome the clash of religions, cultures, and civilizations. According to Kant, “... the education plan should be drawn from a cosmopolitan point of view". As the "Principle of the art of education, that especially should have been kept before the eyes of the people, responsible for the design of the educational plans, states the following: children should be educated not for the present times, but for the future, possibly, for the better condition of the humanity, i.e. for the ideas of the mankind and according to its general purpose" [20]. Humanistic pedagogics should be the most important component in the process of education and upbringing of the younger generation, promoting the establishment of friendship among the nations and states.

\section{REFERENCES}

[1] I. Kant, "Groundwork of the Metaphysics of Morals", Collected Works in 8 Vols. Vol. 6. Moscow: Choro, 1994, p. 533.

[2] V.V. Vasilyev, "I. Kant: Dogmatic Turn into the "Critical" Decade", Immanuel Kant: Heritage and Project. M.: "Kanon+", 2007, p. 202.

[3] M. Heidegger, "The Basic Problems of Phenomeology". SPb: Higher School of Philosophy and Religion, 2001, p. 437. 
[4] I. Kant, "Examination of the Question ... which was set by the Royal Academy of Sciences in Berlin as the Prize Question...”, Collected Works in 8 Vols. Vol. 7. Moscow: Choro, 1994, pp. 378, 384.

[5] W. Windelband, "What Is Philosophy?", Collected Works: Spirit and History. M.: Yurist, 1995, pp. 33-34, 44, 52.

[6] H. Rickert, "Introduction to the Transcendental Philosophy: the Object of Cognition", Philosophy of Life. Kiev: Nika-Center, 1998, p. 159.

[7] E.V. Oznobkina, "To the Heideggerian Interpretation of I. Kant's Philosophy", Historical-Philosophical Yearbook, 1989. Moscow: Nauka, 1989 , p.137.

[8] Brihadaranyaka Upanishad, Upanishads: In 3 Vols. Vol. 1: M.: Nauka, 1992, p. 112.

[9] E. Cassirer, "Philosophy of Symbolic Forms", Culture Studies. XX Century. M.: Yurist, 1995, pp. 208-209.

[10] I. Kant, "Critique of Pure Reason", Collected Works in 8 Vols. Vol. 3. M., 1994, p. 564.

[11] I. Kant, "On Pedagogy”, ibid. Vol. 8, pp. 405, 406.

[12] I. Kant, "Critique of Pure Reason", ibid. Vol. 3, p. 594.

[13] I. Kant, "Religion within the Limits of Reason Alone", ibid. Vol. 6, p. 8.

[14] I. Kant, "The Contest of Faculties". Kaliningrad, Iz-vo KGU, pp. 136, $146,176$.

[15] I. Kant, Ibid, pp. 173-174, 180.

[16] M. Heidegger, Kant and the Problem of Metaphysics. M.: Logos, 1977, p. 5, 1, 3.

[17] B.G. Nurzhanov, "Existence as Text. Philosophy in the Era of Signs (Heidegger and Derrida)", Historical-Philosophical Yearbook. '92. M.: Nauka, 199, p. 167.

[18] V.I. Molchanov, "Husserl and Heidegger: Phenomenon, Ontology, Time", The Problem of Consciousness in the Modern Western Philosophy. M.: Nauka, 1989, pp. 125-126.

[19] I. Kant, "On Pedagogy", p. 406.

[20] Ibid. 